\title{
Relation between Cell Surface Antigenicity of Baker's Yeast and Susceptibility to Lytic Enzymes ${ }^{\dagger}$
}

\author{
Youichi TamaI, Takahiro Nakashima and Masayoshi TaKakUWa \\ Department of Agricultural Chemistry, Faculty of Agriculture, \\ Ehime University, Matsuyama 790, Japan
}

Received September 10, 1979

\begin{abstract}
Upon incubation with lytic enzymes, the antigenic activity of the cell surface of baker's yeast was decreased. Some antigens were released from the cell even when lysis of the yeast cell had not occurred. Thus the relation between retention of antigenic activity on the cell surface and susceptibility to lytic enzymes was investigated with yeast cells treated with heat, 2mercaptoethanol, sodium periodate, several aldehydes, diethyl pyrocarbonate, acetic acid and acetone. The results revealed that susceptibility of the cell surface to lytic enzymes and antigenicity were greatly dependent on the physical and chemical status of either the mannan layer or cell membrane.
\end{abstract}

Many papers ${ }^{1 \sim 6)}$ have been published on microbial enzymes which show lytic activities against yeast cell walls. However, the lytic activities of enzymes toward cells from the stationary phase culture are slight or negligible, unless thiol compound such as 2-mercaptoethanol is present in the incubation mixture. . $^{4 \sim 14 \text { ) }}$

$\beta$-Glucan is the main component of the cell wall of yeast cells ${ }^{15 \sim 17)}$ and it is a general conception that $\beta$-glucanase may play the leading role on lysis of yeast cells. ${ }^{10 \sim 14,18}$ ) However, some investigators have described $^{9.19)}$ from their experiments that certain enzymes other than $\beta$-glucanase are required for lysis of viable yeast cells.

Our previous papers reported that the immunological method of agglutination reaction was effective in detecting minute changes on the surface of baker's yeast cell, such as conformational changes of mannan and glucan layer by physical or chemical treatment. $^{20.21)}$ Therefore, the relation between retention of antigenicity on the cell surface of baker's yeast and its susceptibility to lytic enzymes was investigated.

† Immunochemical Studies on Surface of Yeast Cell. Part IV. For Part III, see ref. 24.

\section{MATERIALS AND METHODS}

Materials. Pressed baker's yeast (Saccharomyces cerevisiae) with no additives was obtained from Oriental Baker's Yeast $\mathrm{Co}$. and stored at $0 \sim 5^{\circ} \mathrm{C}$. The yeast was used as fresh, within a month after arrival. The antiserum against fresh yeast cell was prepared as described in the previous paper. ${ }^{20}$ The antibody titer estimated by the agglutination method was 640. "Zymolyase-5000" prepared from the culture broth of Arthrobacter luteus and Pellicularia sasaki enzyme (P-enzyme) prepared from the culture filtrare of Pellicularia sasaki were used as yeast cell lytic enzymes. The former was a gift from the Research Laboratories of Kirin Brewery Co., and the latter, from Prof. S. Nagasaki of Kochi University. All chemicals used were of the purest grade available.

Enzyme assay. For lytic activity of Zymolyase, the reaction mixture was composed of $9 \mathrm{ml}$ of yeast cell suspension (about $12 \mathrm{mg}$ pressed yeast), $0.9 \mathrm{ml}$ of $\mathrm{M} / 15$ phosphate buffer ( $\mathrm{pH} \mathrm{7.5)} \mathrm{and} 0.1 \mathrm{ml}$ of enzyme. The mixture was incubated at $25^{\circ} \mathrm{C}$ for $120 \mathrm{~min}$ with gentle shaking and the turbidity was measured at $800 \mathrm{~nm}\left(A_{800}\right)$ with a Hitachi Spectrophotometer Model 124. As a reference, $0.1 \mathrm{ml}$ of water was used instead of enzyme solution. The initial absorbance of the reference was about 0.6 . The lytic activity was expressed by the difference in absorbance $\left(\Delta A_{800}\right)$ and sometimes by the percentage of decrease in absorbance $=$ (initial $A_{800}$ of reference $-A_{800}$ of reaction mixture) $\times 100 /$ initial $A_{800}$ of reference. The lytic activity of $\mathrm{P}$-enzyme was determined according to the method of Yamamoto and Nagasaki. ${ }^{22}$ The reaction mixture was composed of $0.5 \mathrm{ml}$ of yeast cell suspension in PR-buffer $(0.02 \mathrm{M}$ phosphate buffer in $0.6 \mathrm{M}$ potassium 
Table I. Effect of Lytic Enzyme on Antigenicity of Yeast Cell Surface

\begin{tabular}{|c|c|c|c|c|c|c|c|}
\hline \multirow{3}{*}{$\begin{array}{l}\text { Dilution } \\
\text { of } \\
\text { antiserum }\end{array}$} & \multicolumn{7}{|c|}{ Agglutination reaction after absorption by yeast cell treated with } \\
\hline & \multirow{2}{*}{ Blank } & \multirow{2}{*}{$\begin{array}{l}\text { Fresh } \\
\text { yeast }\end{array}$} & \multicolumn{2}{|c|}{ Zymolyase $(\mathrm{mg})^{a}$} & \multicolumn{3}{|c|}{ P-enzyme $(\mathrm{mg})^{b}$} \\
\hline & & & 1.2 & 2.4 & 12.5 & 25.0 & 50.0 \\
\hline 40 & ++ & \pm & $++^{c}$ & ++ & ++ & ++ & ++ \\
\hline 80 & ++ & - & ++ & ++ & + & + & + \\
\hline 160 & ++ & - & ++ & ++ & \pm & + & + \\
\hline 320 & ++ & - & ++ & ++ & \pm & \pm & + \\
\hline 640 & ++ & - & ++ & ++ & - & - & \pm \\
\hline
\end{tabular}

- Relative degrees of lysis to 1.2 and $2.4 \mathrm{mg}$ of Zymolyase were 0.6 and $0.7 \%$, respectively.

b Relative degrees of lysis to $12.5,25.0$ and $50.0 \mathrm{mg}$ of P-enzyme were $0.3,1.5$ and $1.8 \%$, respectively.

c The states of agglutination: ++ , detected with the naked eye; + , detected clearly only under microscope; \pm , detected slightly under microscope; -, not detected under microscope.

chloride, $\mathrm{pH} 6.0)(1.0 \mathrm{ml})$ and $0.5 \mathrm{ml}$ of P-enzyme solution, and incubated at $40^{\circ} \mathrm{C}$ for $60 \mathrm{~min}$ with gentle shaking. Then $5 \mathrm{ml}$ of water was added and the mixture was shaken for $10 \mathrm{~min}$ to allow the protoplasts to burst by osmotic and mechanical shock, and the absorbance at $600 \mathrm{~nm}$ was measured. As a reference, $0.5 \mathrm{ml}$ of water was used instead of enzyme solution. The lytic activity of P-enzyme was expressed by the percentage of decrease in absorbance calculated by the same equation used for Zymolyase activity.

Physical and chemical treatment of yeast cells. The treatment of yeast cells with heat, 2-mercaptoethanol or sodium periodate was carried out according to procedures reported previously. ${ }^{20,211}$

Antigenicity. The antigenicity of the yeast cell surface which had been treated with various chemicals or enzymes was estimated by determining the remaining agglutination reactivity, according to the method described in the previous paper. ${ }^{20)}$ The antigenic components solubilized by lytic enzymes were detected by Ouchterlony double immunodiffusion test.

\section{RESULTS}

\section{Effect of lytic enzymes on antigenicity}

Table I shows the effects of lytic enzymes on antigenicity of yeast cell surface. A decrease in antigenic activity was clearly demonstrated even by incubation with low lytic activities of enzymes. The effect of zymolyase on the decrease of antigenic activity was significantly greater than that of P-enzyme.

The result suggested that treatment to decrease antigenic activity might increase the . susceptibility of yeast cells to lytic enzyme. Hence, the effects of various physical or chemical treatments, found to decrease cell surface antigenic activity, on susceptibility to lytic enzyme was examined. The effects of various treatments known to increase the activity of lytic enzymes $\left.{ }^{7} \sim 10,12\right)$ on the antigenicity of the yeast cell surface were also investigated.

Table II shows the effect of heating on susceptibility of yeast cells to Zymolyase. The susceptibility to Zymolyase was not increased by heating at $60^{\circ} \mathrm{C}$ for $10 \mathrm{~min}$, but increased in geometrical progression at temperatures over $80^{\circ} \mathrm{C}$. This increased susceptibility to Zymolyase by heating was found to result in decreased cell surface antigenic activity. ${ }^{20)}$

Table II. Effect of Heating on Susceptibility to ZYMOLYASE

The yeast cell supensions were heated at various temperatures for $10 \mathrm{~min}$, and after cooling to $25^{\circ} \mathrm{C}$, a certain amount of $Z$ ymolyase was added to the respective suspension. $\Delta A_{800}$ was determined for the mixture after $120 \mathrm{~min}$ incubation.

\begin{tabular}{ccc}
$\begin{array}{c}\text { Temperature } \\
\left({ }^{\circ} \mathrm{C}\right)\end{array}$ & $\Delta A_{800}$ & $\begin{array}{c}\text { Relative degree of } \\
\text { cell lysis }(\%)\end{array}$ \\
\hline Not heated & 0.012 & 2.4 \\
40 & 0.014 & 2.8 \\
60 & 0.016 & 3.2 \\
80 & 0.043 & 8.7 \\
100 & 0.088 & 17.8 \\
\hline
\end{tabular}


TABLE 1II. EFFECT OF 2-Mercaptoethanol ON Yeast Cell Antigenicity

The yeast suspension was incubated with $0.5 \mathrm{M} 2$ mercaptoethanol at $30^{\circ} \mathrm{C}$ for $30 \mathrm{~min}$ and examined for antigenic activity.

\begin{tabular}{|c|c|c|c|}
\hline \multirow{2}{*}{$\begin{array}{c}\text { Dilution } \\
\text { of } \\
\text { antiserum }\end{array}$} & \multicolumn{3}{|c|}{ Agglutination reaction after absorption by } \\
\hline & Blank & Fresh yeast & Treated yeast \\
\hline 40 & ++ & \pm & + \\
\hline 80 & $+t$ & - & \pm \\
\hline 160 & ++ & - & \pm \\
\hline 320 & ++ & - & \pm \\
\hline 640 & ++ & - & - \\
\hline
\end{tabular}

Relative degrees of lysis of fresh yeast and $0.05 \mathrm{M} 2-$ mercaptoethanol treated $\left(30^{\circ} \mathrm{C}, 30 \mathrm{~min}\right)$ yeast to Zymolyase were 2.4 and $5.1 \%$, respectively.

Table IV. Effect of Treatment with Sodium Periodate ON Susceptibility to Zymolyase

The yeast suspension was treated with sodium periodate at $25^{\circ} \mathrm{C}$ for $10 \mathrm{~min}$ and then incubated with Zymolyase from $120 \mathrm{~min}$.

\begin{tabular}{cc}
\hline $\begin{array}{c}\text { Concentration of } \\
\text { sodium periodate }(\mathrm{M})\end{array}$ & $\begin{array}{c}\text { Relative degree of lysis } \\
(\%)\end{array}$ \\
\hline 0 & 2.4 \\
0.005 & 2.0 \\
0.01 & 1.4 \\
0.02 & 0.8 \\
\hline
\end{tabular}

The effects of 2-mercaptoethanol on susceptibility to Zymolyase and on antigenic activity of the cell surface are shown in Table III. Treating yeast cells with $0.05 \mathrm{~m} 2$-mercaptoethanol at $30^{\circ} \mathrm{C}$ for $30 \mathrm{~min}$ increased susceptibility to Zymolyase approximately twice and decreased antigenic activity by three steps in dilution, but the agglutination reactivity of antisera absorbed by treated cells displayed \pm in all three steps of dilution.

Sodium periodate has been known to markedly decrease the antigenic activity of the cell surface ${ }^{21)}$ and the effects of treatment with this reagent on susceptibility of yeast cells to Zymolyase were examined. Table IV shows the results. Treatment of yeast cells with $0.01 \mathrm{M}$ sodium periodate at $25^{\circ} \mathrm{C}$ for $10 \mathrm{~min}$ clearly decreased the susceptibility to lytic enzyme. This treatment also decreased the antigenic
Table V. EfFects of Various Chemical REAGENTS ON SUSCEPTIBILITY TO ZYMOLYASE

Yeast cells treated with the indicated chemicals were incubated with lytic enzyme for $120 \mathrm{~min}$.

\begin{tabular}{|c|c|c|}
\hline Chemicals & $\begin{array}{l}\text { Relative } \\
\text { degree of } \\
\text { lysis }(\%)\end{array}$ & $\begin{array}{c}\text { Antigenic } \\
\text { activity }\end{array}$ \\
\hline Control (No treatment) & 3.0 & - \\
\hline Formaldehyde $(40 \%)$ & 3.0 & $\downarrow$ \\
\hline Acetaldehyde $(40 \%)$ & 3.0 & $\downarrow$ \\
\hline Glutaraldehyde $(5 \%)$ & 3.0 & - \\
\hline Diethylpyrocarbonate $(1 \%)$ & 2.8 & $\downarrow$ \\
\hline$---\cdots--1$ & --- & $---\cdots$ \\
\hline Acetone $(10 \mathrm{~min})$ & 7.9 & - \\
\hline Acetone $(120 \mathrm{~min})$ & 7.9 & - \\
\hline AcOH-vapour & 7.3 & - \\
\hline $\mathrm{AcOH}$-acetone-ether & 7.3 & - \\
\hline
\end{tabular}

Antigenic activity of yeast cells: - not changed; $\downarrow$, decreased.

Table VI. Effect of Alternative Treatment of Yeast Cells with Acetic Acid and Sodium Periodate on SUSCEPTIBILITY TO ZYMOLYASE

\begin{tabular}{cc}
\hline Treatment & Relative degree of lysis $(\%)$ \\
\hline $\mathrm{AcOH}$ & 7.3 \\
$\mathrm{AcOH}-\mathrm{NaIO}_{4}$ & 6.3 \\
---- & --7 \\
$\mathrm{NaIO}_{4}$ & 1.4 \\
$\mathrm{NaIO}_{4}-\mathrm{AcOH}$ & 2.9 \\
\hline
\end{tabular}

activity of the cell surface, as reported previously. ${ }^{21)}$ The susceptibility was reduced onethird by treatment with $0.02 \mathrm{M}$ sodium periodate.

Effects of various agents on susceptibility to Zymolyase and antigenicity

Table $\mathrm{V}$ shows the changes in susceptibility to Zymolyase of yeast cells treated with various chemical reagents. These chemical reagents caused a slight decrease in cell surface antigenic activity. ${ }^{21)}$ Chemicals which react with protein caused a slight decrease in antigenic activity, but produced little to no effect on susceptibility. On the other hand, chemicals which affect membrane lipid but not 
antigenic activity increased susceptibility to lytic enzyme (about 2.5 times).

Table VI shows the effect of alternative treatments with acetic acid and sodium periodate on susceptibility of yeast cells to Zymolyase. Acetic acid treatment increased susceptibility which was reduced by treatment with sodium periodate, on the other hand, sodium periodate reduced susceptibility which was increased by acetic acid.

Variation in antigenicity and susceptibility to Zymolyase during storage of pressed yeast

Pressed baker's yeast usually becomes a mash, colored brown on storage at $30^{\circ} \mathrm{C}$ for about 10 days. The phenomenon is called "liquefaction or softening." The antigenic activity and susceptibility to Zymolyase of yeast cells stored at $30^{\circ} \mathrm{C}$ were thus investigated. Table VII shows the variations in antigenic activity on the cell surface of pressed baker's yeast on storage at $30^{\circ} \mathrm{C}$ for varying length of time. The antigenic activity was unchanged up to 8 days of storage, but markedly decreased after 11 days, when the socalled softening was observed.

Table VIII shows the variation in susceptibility of yeast cells to Zymolyase during storage of pressed baker's yeast at $30^{\circ} \mathrm{C}$. The susceptibility of fresh yeast to lytic enzyme increased gradually, but rapidly, later in storage. Treatment with sodium periodate resulted in less susceptibility to Zymolyase, but this effect was gradually lost later in storage,

Table VII. Variations in Antigenic Activity on Cell Surfaces during Storage of Pressed Baker's Yeast

\begin{tabular}{cccccccccc}
\hline $\begin{array}{c}\text { Dilution } \\
\text { of } \\
\text { ontiserum }\end{array}$ & \multicolumn{8}{c}{$\begin{array}{c}\text { Agglutination reaction after absorption } \\
\text { by yeast cells }\end{array}$} \\
\cline { 2 - 8 } & Blank & 0 & 2 & 4 & 6 & 8 & $10^{b}$ (days) \\
\hline 40 & ++ & \pm & \pm & \pm & \pm & \pm & ++ \\
80 & ++ & - & - & - & - & - & ++ \\
160 & ++ & - & - & - & - & - & \pm \\
320 & ++ & - & - & - & - & - & - \\
640 & ++ & - & - & - & - & - & - \\
\hline
\end{tabular}

a $30^{\circ} \mathrm{C}$.

${ }^{b}$ Softening was detected.
Table VIII. Variation In Susceptibility of Yeast Cells to Zymolyase during Storage of Pressed BaKer's YEAST AT $30^{\circ} \mathrm{C}$

Pressed baker's yeast was stored at $30^{\circ} \mathrm{C}$ until softening was observed. The susceptibility to Zymolyase was expressed relatively by the ratio of the value $(1.00)$ of 0 day storage.

\begin{tabular}{lccccccc}
\hline & \multicolumn{6}{c}{ Dusceptibility of yeat } \\
\cline { 2 - 7 } & 0 & 2 & 4 & 6 & 8 & 10 \\
\hline $\begin{array}{l}\text { No treatment } \\
\text { Treated with }_{\mathrm{NaIO}_{4}{ }^{a}}\end{array}$ & 1.00 & 1.00 & 1.10 & 1.75 & 2.00 & 4.59 \\
\hline
\end{tabular}

a Treated with $0.02 \mathrm{M}$ of $\mathrm{NaIO}_{4}$ for $10 \mathrm{~min}$.

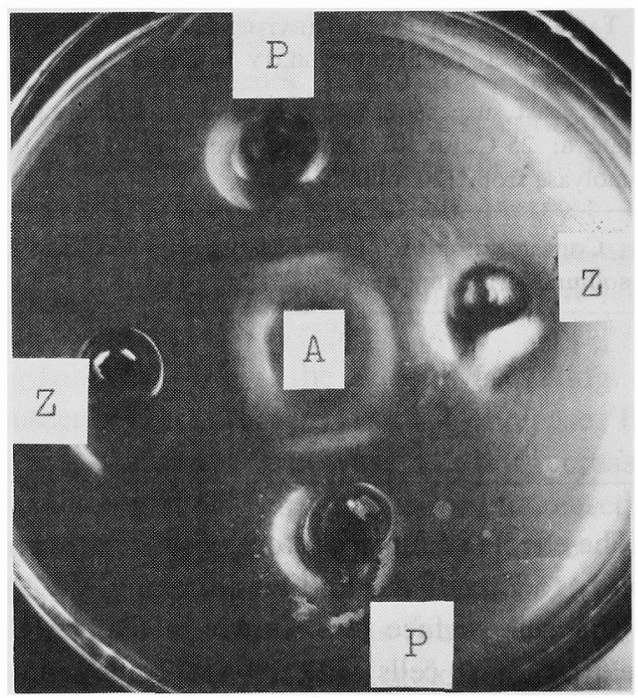

Fig. 1. Ouchterlony Double Immunodiffusion Test of Anti-yeast Serum against Enzymatic Hydrolyzate.

Ouchterlony double diffusion analyses were done on $1 \%$ agar containing $0.85 \% \mathrm{NaCl}$. Z, Zymolyase digest; P, Penzyme digest; A, antiserum.

and the susceptibility to lytic enzyme in the treated cells increased greater than that of untreated cells on 10 days stotage at $30^{\circ} \mathrm{C}$.

\section{Release of antigens by lytic enzymes}

To detect the cell wall mannan released by lytic enzymes, the Ouchterlony double immunodiffusion test was performed. As shown in Fig. 1, two precipitation lines were observed 
between the antiserum and the two digests, the digest with Zymolyase and the digest with $\mathrm{P}$ enzyme. Furthermore, respective lines fused with each other between the hydrolysates, suggesting that the two digests were immunologically identical.

\section{DISCUSSION}

$\beta$-Glucan, a basal component of polymers which construct the cell wall of baker's yeast, is known to be highly polymerized and branched $\beta$-1,3-glucan containing a significant amount of $\beta$-1,6-glucosidic linkage. According to Kidby and Davies, ${ }^{23)}$ certain protein molecules mediate between the mannan-glucan layers or mannan layer, and the glucan layer builds up around the yeast cell membrane. The two lytic enzymes used in the present study have been reported to be an endo-glucanase and liberate laminaripentaose predominantly on incubation with various $\beta$-glucans. ${ }^{14,24}$, The results shown in Table I indicate that the enzyme active in decreasing the antigenic activity of yeast cell surface was also more active in lytic action. Moreover, lysis of yeast cells was accompanied by some damage of the outer layer, mainly constructed from mannan, of the yeast cell wall. Measurement of antigenic activity of the yeast cell surface may thus be useful for studying the mechanism involved in lysis by enzymes. The fact that two fused precipitation lines against the antiserum were detected between Zymolyase- and P-enzymedigests where negligible lytic activities were observed suggests that detecting the release of cell surface antigen might be used as a sensitive criterion for yeast cell lysis.

The susceptibility of yeast cells to Zymolyase was markedly increased by heating yeast cells at $80^{\circ} \mathrm{C}$ for $10 \mathrm{~min}$. The antigenic activity of the yeast cells was decreased by heating the cells at $60^{\circ} \mathrm{C}$ for $10 \mathrm{~min}$, and more markedly decreased by heating at $80^{\circ} \mathrm{C}$ to $100^{\circ} \mathrm{C}$. Therefore, the increase in susceptibility to Zymolyase may be due to a damage in antigenic substances on the cell surface. heattreatment, however, may not cause the ruptur- ing of the antigenic determinants existing in the mannan molecule moieties, because the cell wall mannan preparation was usually obtained after autoclaving the yeast cells. ${ }^{25}$, Thus a certain heat-labile substances must be present and contribute to the antigenicity of the yeast cell surface, because considerable amounts of antibodies remained even after the antibodies had been completely absorbed by the cell wall mannan preparation. ${ }^{26)}$ The existence of certain heat-labile antigen was detected in Zymolyase-digest of fresh yeast, and one of them was isolated from yeast cell wall. ${ }^{27)}$

The susceptibility to Zymolyase was increased about twice by treatment with 2mercaptoethanol. But the increase by this treatment was still less compared with heattreatment. Mercaptoethanol may not damage the cell wall mannan, but it may break the disulfide bonds of the protein which exists in a inner matrix formed by the structural mannan or mannan-protein. This conception is supported by the result that 2-mercaptoethanoltreatment did not cause so severe decrease in antigenic activity as heat-treatment.

Oxidation with sodium periodate caused a marked decrease in antigenic activity of the cell surface. However, the oxidation rather decreased the susceptibility to Zymolyase. The susceptibility of yeast cells treated with $0.01 \mathrm{M}$ periodate was only half of the control, although there was little effect on the viability of yeast cells and antigenic activity decreased by one step. ${ }^{21)}$ Periodate oxidizes cell wall mannan to produce aldehyde groups. This chemical reaction may proceed from the outer region of the cell to the inner. ${ }^{21}$ The effect on susceptibility to Zymolyase described above might be due to the aldehyde groups produced. Further, the possibility remains that the carboxyl groups derived from aldehyde groups hindered approach of Zymolyase to the $\beta$ glucan layer. The hydrolysis of this glucan leads to lysis of yeast cells.

As shown in Table $\mathrm{V}$, the reagents which affected membrane lipid but had no effect on antigenic activity of the cell surface, increased the susceptibility to Zymolyase. This effect 
might be wobble occurred in the structure of the glucan layer to facilitate the attack of Zymolyase through degradation of the cell membrane, because reagents had no effect on the mannan layer. Moreover, as shown in Table VI, treatment with acetic acid increased the susceptibility to Zymolyase which was reduced by treatment with periodate. This result indicates that the sites of the cell surface to be influenced by acetic acid and periodate are different. It may be concluded from the present study that the susceptibility of yeast cells to $\beta$-glucanase varies according to the physical and chemical status of either the mannan layer or cell membrane. Several papers have reported that there are some contradictions between activities obtained using soluble substrate and vegetative yeast cells. ${ }^{28,29)}$ Such contradictions are considered natural from the present experiments. Therefore, the action of lytic enzymes should be studied in connection with physical and chemical status of the cells employed.

Nevertheless, investigations on antigenic activity of the cell surface and susceptibility to lytic enzymes may be very useful to elucidate the fine structures in the cell surface. The results in Tables VII and VIII suggest that autodegradation of cell membrane occurs gradually from middle stage of storage.

Acknowledgments. We wish to express our thanks to Prof. S. Nagasaki of Kochi University for the gift of Pellicularia sasaki enzyme and the Research Laboratory of Kirin Brewery $\mathrm{Co}$. for the gift of Zymolyase-5000. This work was supported in part by a grant from the Mishima Kaiun Memorial Foundation.

\section{REFERENCES}

1) M. R. J. Salton, J. Gen. Microbiol, 12, 25 (1955).

2) T. Kaneko, K. Kitamura and Y. Yamamoto, J. Gen. Appl. Microbiol., 15, 317 (1969).
3) G. G. Jones and C. E. Ballou, J. Biol. Chem., 224, 1052 (1969).

4) Y. Yamamoto, Kagaku to Seibutsu, 10, 709 (1972).

5) H. Tanaka and H. J. Phaff, J. Bacteriol., 89, 1570 (1965).

6) A. A. Eddy and D. H. Williamson, Nature, 183, 1101 (1957).

7) K. Horikoshi and K. Sakaguchi, J. Gen. Appl. Microbiol., 4, 1 (1958).

8) R. Dauties and P. A. Elvin, Biochem. J., 93, 8 (1964).

9) S. Nagasaki, N. P. Neumann, P. Arnow, L. D. Schnable and J. O. Lampen, Biochem. Biophys. Res. Commun., 25, 158 (1966).

10) S. Yamamoto, R. Kobayashi and S. Nagasaki, Agric. Biol. Chem., 38, 1563 (1974).

11) M. Mada, K. Hirao, Y. Kimura and K. Noda, Nippon Nôgeikagaku Kaishi, 45, 269 (1971).

12) T. Kaneko, K. Kitamura and Y. Yamamoto, Agric. Biol. Chem., 37, 2295 (1973)

13) K. Kitamura, T. Kaneko and Y. Yamamoto, J. Gen. Appl. Microbiol, 20, 323 (1974).

14) K. Doi, A. Doi and S. Nakamura, Agric. Biol. Chem., 40, 1669 (1976).

15) M. Hayashibe, Kagaku to Seibutsu, 4, 682 (1966).

16) M. Hayashibe, Kagaku to Seibutsu, 13, 410 (1975).

17) T. Nakajima and C. E. Ballou, J. Biol. Chem., 249, 7685 (1974).

18) Y. Yamamoto, Kagaku to Seibutsu, 10, 709 (1972).

19) F. B. Anderson and J. W. Millback, Biochem. J., 99, 682 (1966).

20) M. Takakuwa, H. Koshitani and Y. Tamai, Mem. Coll. Agric., Ehime Univ., 21, 179 (1976).

21) M. Takakuwa, H. Koshitani and Y. Tamai, $J$. Ferment. Technol., 54, 856 (1976).

22) S. Yamamoto and S. Nagasaki, J. Ferment. Technol., 50, 117 (1972).

23) D. K. Kidby and R. Davies, J. Gen. Microbiol,, 61, 327 (1970).

24) S. Nagasaki, in preparation.

25) S. Suzuki and H. Sunayama, Tanpakushitsu Kakusan Koso, 19, 1094 (1974).

26) Y. Tamai, T. Nakashima, M. Takakuwa and A. Misaki, Agric. Biol. Chem., 44, 49 (1980).

27) $Y$. Tamai and $M$. Takakuwa, in preparation.

28) H. Tanaka and H. J. Phaff, J. Bacteriol., 89, 1570 (1965).

29) N. Toyama and K. Ogawa, J. Ferment. Technol, 46, 626 (1968). 